\title{
Innovative Approaches of Political Education in Ukraine: On the Example of Developed Western Democracies
}

\author{
Nataliia H. Iskhakova* \\ Leonid V. Chuprii ${ }^{1}$ \\ Lyudmyla I. Lyasota ${ }^{1}$ \\ Liudmyla V. Bondar ${ }^{2}$ \\ Natalia B. Lytvynchuk ${ }^{2}$ \\ ${ }^{1}$ Department of Sociology and Political Science, \\ Faculty of Linguistics and Social Communications, \\ National Aviation University, Kyiv, Ukraine \\ ${ }^{2}$ Pedagogy and Psychology of Professional Education Department, \\ Faculty of Linguistics and Social Communications, \\ National Aviation University, Kyiv, Ukraine \\ ${ }^{*}$ Corresponding author
}

Doi: 10.36941/ajis-2020-0030

\section{Abstract}

This article was composed to discuss the particular traits of the contemporary political education of students in Ukraine. A system of political education is introduced to develop the fundamental political knowledge and skill-set of students, as well as aiding in the formation of their civic consciousness. The innovative modernization approaches are represented by American Political Science Association. The main purpose of the research to show modernization methods of political education what is the basis for the formation of democratic values of Ukrainian society. Much attention is paid to the correlation between civic and political education. The need for value content of political education adds to the urgency of the study. This involves making greater use of the tools of political education to support the dialogue of cultures in the modern world. Ensuring that society is prepared to solve global problems by developing the active position and individual responsibility of each young person should be an equally important result of political education in the 21st century. Political education now requires a walkthrough approach of implementation (through project initiatives, socio-cultural activities, networking and various types of cooperation between those who get education in the socio-political sector). The authors emphasize that it is worth rethinking the new opportunities of social networks, the Internet era to build youth initiatives and teams for project work. However, one of the challenges of the information society is the dominance of different types of data ("information noise"), which requires young people to have a higher level of media literacy and more developed critical thinking. Systematization literary sources and approaches for solving the problem indicates that the new systems of political values have been formed, which are essential for the democratization. Two groups of mutually perceived values were approved. The first group is dominant. It is associated with values such as security, sovereignty, patriotism, freedom, human rights, justice, political stability. The second group of established values is evolving: legality, responsibility, equality, political pluralism, legitimacy. This article reveals the understanding of these values of Ukrainian citizens on the basis of Ukrainian and European sociological research.

Keywords: political education, civic (citizenship) education, political socialization, political participation, democratization, political value system 


\section{Introduction}

The relevance of this subject is defined by sharpness which is gained by a problem of lack of political knowledge and competence of student's youth. More than a half of citizens for decades of independence of Ukraine admitted that they do not have enough political knowledge, experience of political activity. Therefore, need of political education is becoming increasingly relevant in Ukraine. It can become an additional tool of assimilation of democratic values, norms, behavior models. The USA can become an example where teaching political science had the purpose of forming of democratic political culture of youth and commitment to democracy values from the middle of the 19th century.

Today, the younger generation in Ukraine has to become a full-fledged subject of political activity and the relations without which participation cardinal social and political changes are impossible. Just the youth concentrates the main tendency of development of society. Our analysis highlights the unfavorable trend of Ukrainian society to increase spontaneous protests in contrast to the inability to establish organized forms of political participation. This tendency can be identified throughout modern Ukrainian history and is especially prevalent in the events of 2004 and 2013-2014. Therefore, a problem of conscious participation of young citizens in implementation of the government and perception of policy by them as spheres of personal interest and responsibility becomes especially acute.

\section{Literature Review}

Researches of interrelation of political education and political participation of youth were begun within cognitive school in psychology (Shestopal, 1988). The process of thinking was an object of researches. The very idea of communication of age opportunities of the personality and its perception of political meanings are fruitful as it allows to track process of formation of political consciousness from a position of development of the personality itself, internal regularities of formation of its thinking (Przeworski, 1991).

Other direction of researches of political education was entered by psychologists - cognitive scientists Jehuda, Morrison, etc. (Shestopal, 1988). They analyzed purposeful influence of factors (agents) of socialization among which school institutions were determined the most influential factors with the help of which political values at the younger generation are formed and standards of political system are assimilated.

The interpretation of the active personality consists within cognitive school having certain political thinking, acts as base for the choice of certain political behavior. The individual makes the type of political thinking in the course of formation of political consciousness, a picture of political reality through which perceives policy, makes decisions and acts. Such direction of researches proceeds in a number of concepts of political training.

Modern researches in the field of political education began within the West German school of political didactics. In the course a combination of problems of political socialization and education the work of Heitmeyer and Jacobi (1991) was published. Shcherbinin (1996) noted, that works in the field of political didactics represent a transition from the theory of political socialization to practice of political education orienting on political process.

From 6oth years of the 2oth century in German practical programs of assimilation of political knowledge by youth were developed. Practical orientation becomes the main line of a system of political education. This is because the process of formation of political consciousness of youth is closely connected with social and political experience of young people.

American scientists Almond and Verba (1992) emphasized that training acts as a component of process of political socialization that causing political orientations of the individual. The assimilation of the political knowledge forms models of political behavior of the younger generation (Almond \& Verba, 1992). 
The problem of definition of ways of assimilation and transfer of the systematized political knowledge through an education system becomes more and more urgent in domestic scientific literature. The purpose of this article is to define the ways of modernization of political education of Ukraine on the basis of the international innovative approaches.

Modern scholars view the problems of political education in the light of the threats and challenges posed by the information society. Youth is a mobile social group open to IT newlydesigned products and applications. However, this raises the problem of media literacy, critical thinking and proper rethinking of information and news by a young person. There is a need to familiarize yourself with the analysis of the event from different sources in order to make its objective assessment. This is time consuming, but demonstrates the responsible position of a consciously thinking person. Thus, the development of the civic culture of young people, their prudent position to engage in social and political life not in a protest, but in a constructive way, to build democracy, to protect human rights and the principles of social justice become more relevant. For example, modern researchers Zijun $\mathrm{Hu}$ and Lia Li agree that the Internet era creates many opportunities for project work, team building and collaboration. However, in acquiring the skills to communicate with the computer, scientists believe that young people are still a kind of aboriginal people in the information society $(\mathrm{Hu} \& \mathrm{Li}, 2018)$. A young man becomes dependent on the evaluative judgments of many strangers. On the other hand, the Internet is an opportunity to unite certain destructive forces in the public sector and manipulate public opinion. Therefore, political education should include an important value concept that will foster the development of a culture of civic consciousness among young people, an understanding of the importance of diversity and building of a society based on consensus polylogue.

According to the theorists Zafer Kus and Orge Tarhan, modern political education of the youth should be walkthrough, i.e. not limited to a single subject or module, but implemented through a variety of teacher initiatives outside the educational institution - support for youth project activities, educational activities in social and cultural institutions, etc. (Kus \& Tarhan, 2016). Therefore, it is important that political education should not have a politicized but value colouring.

The Polish scholar T. Szkudlarek discusses whether the current political education of young people can support the "depoliticized" dimension of political realities (Szkudlarek, 2013). Theorist emphasizes that most global problems of the modern world require responsible individual solutions and self-management. And this trend - teaching young people to be responsible for themselves and, therefore, for the society in general - also has a clear value colouring. So we can say that the basis of political education is the values of responsibility, social justice and integrity. Civic education (a slightly broader concept than political education), in fact, contains patterns of political education. Thus, the development of political education depends on the success of civic education programs, and vice versa. We will further develop this understanding in this publication.

The relationship between modern education and politics requires new articulations. Education is a practice that reconfigures the relationship between the individual and the public. Political education, among other things, forms a discourse that leads to either social conflict or consensus. Modern approaches to political education should ensure maximum use of the educational potential of the society for the development of political processes, civil society, democratic development of all social structures.

\section{Metodology}

The study has a broadly interdisciplinary character, which is reflected in the choice of a broad methodological tools. The theoretical and methodological basis of the study is a set of philosophical, general scientific and specific political science research methods that provide a systemic analysis of the phenomenon of political education in the context of a democracy. In the course of the research, the content analysis of the current domestic and foreign publications on the topic of political education was carried out. The structural and functional approach was used for the comprehension 
of political education as a system, process and result. The study used a historical method that allowed analyzing the background of the formation of democratic political culture of Ukrainian youth and the impact of political education on this process in retrospect. A substantive analysis of the concept of "political education" in the classical and modern theories of politics was accomplished. The findings of the study are substantiated by providing the empirical data, in particular the results of mass sociological surveys in Ukraine conducted by reputable international organizations/projects on the development of civic education and/or education for a democratic society.

\section{Results}

Two interconnected concepts: civic and political education meet in the researches devoted to this question.

Civic education is a complex of teaching and educational work combining elements political, economic, legal, ethical education. The purpose of teaching and educational actions is formation of the citizen, capable being guided by the existing legislative base, to protect his rights and freedoms, to give support to political forces which can really represent his interests at the level of the local and supreme bodies of the government (Ivanov, 2003).

The formation of public consciousness includes political education as component of civic education. This is a training of young citizens of life in the conditions of the modern democratic state (Zhadan et al., 2004). The sense of responsibility, debt, patriotism (feeling of solidarity, participation in the historical fate of the homeland and its people), understanding itself of as full member of social community, citizen of the country, a maturity of political and legal consciousness, respect for the rights and duties lie in the base of civic consciousness. Compliance with laws, upholding of own rights, satisfaction of social requirements and interests with democratic methods have to be the basic practical skills of the citizen. Political education is directed to formation at the individual of certain qualities of the citizen.

As a result, the establishment of a citizen's knowledge, duties and right, as well as a direct and representative democracy's constitutional and legal process (including the principles of suffrage, political gathering, referendum, and the demonstration process among others) embody the main aspect of political education. The primary goal of political education is to utilize critical political thinking and proper evaluation of political events to foster a rational selection of political stances and positions.

Political education incorporates many stages. These educational phases include personal familiarization of political figures and symbols of the state, as well as the recognition of behavioral norms in the political process. Also incorporated is a thorough study of the structure and function of political institutes, analyzing the concept of political value and the application of rational thinking to the establishment of policy. (Iskhakova, 2018a; 2018b).

The child gradually develops in the course of training. There are important psychological changes in intellectual development. In school days, namely transition from empirical knowledge to theoretical, from direct sensory perception of political reality to generalized and abstract concepts. Deeper level of assimilation of political and legal knowledge occurs in a higher educational institution.

The purpose of introduction of a system of political education in the university is formation at students of a system of basic knowledge, development of skills of theoretical and practical bases of implementation of policy as public phenomenon, assistance to formation of civic consciousness of students.

The task of studying of the corresponding disciplines is in giving to students of knowledge of features of policy as the public phenomenon, structure and typology of political system of society. An image of the state as main political institute of society has to be created in consciousness of young citizens. Despite rapidity and sharpness of political processes in modern Ukraine, educated youth should have steady knowledge of the main kinds of a political regime and stages of electoral process 
in the democratic country. The students should understand an entity of political parties and groups of interests in society and also a role of the personality in political process in order to realize ways of implementation of own interests in policy. Racks of knowledge of main spheres of foreign policy activity of Ukraine will give the chance to youth to understand the strategy of development for own country on the international scene.

The political education has "to arm" young citizens with knowledge of the most various modern political phenomena and processes of own country and the world:

- origin, entity and social conditionality of politics;

- specifics of the political power, the political relations and processes, in particular, in modern Ukraine;

- $\quad$ structure, typology of political system of society and main forms of the state as its main institute;

- the main directions of state policy and the system of executive power in Ukraine;

- parameters of the analysis of a political regime, its versions and political principles of modern democracy;

- features of elections as forms of direct democracy in Ukraine, versions of electoral systems and stages of electoral process in modern Ukraine;

- types of political parties and party systems, functions of groups of interests in politics;

- types of political behavior and forms of political participation;

- entity and main directions of world politics, international relations, global problems of the present.

The system of political education and education is an effective specific institute of primary political socialization, provides occurrence of new generations to difficult world of politics. An organic inclusion in a complex system of the political relations and institutes through formation of idea of the state, the power in society at the daily level, formation of models of political behavior, the relation to political roles in the future, preparation for political life, establishment of a ratio of norms and deviations in political consciousness and behavior is its content. Therefore, the gained knowledge has to be supported by the following abilities of young citizens:

- to define own position in social structure of society;

- to analyze ways of realization of own social requirements and interests in the political sphere;

- to establish a form of government and the device of modern Ukraine and the countries of the world;

- to acquire powers of the supreme bodies of the government of Ukraine (being guided by the Constitution of Ukraine);

- to prove the principles of the constitutional state and to establish the level of realization of constitutional rights and freedoms of people and the citizen in Ukraine;

- to take conscious part in electoral process of Ukraine and to apply standards of electoral laws during elections;

- to analyze the structure of civil society in Ukraine and to form own political position on the basis of awareness of own requirements and interests;

- to resist to manipulative impacts on political consciousness of citizens.

American political scientists have presented a fundamental study of the trends in the development of political science in the 21st century. The study was conducted within American Political Science Association (2011).

APSA Teaching and Learning Conferences consistently highlight the crucial requirement to associate political science with actual real-world events. The implication of this thinking is that political scientists should more extensively incorporate current events into their educational presentations. Examples of courses that could easily be made more relevant to students by tailoring them to include current events are those that focus on civic engagement, international issues and policy development. The inclusion of current events within the structure of classes increases the 
chances that students and citizens remain engaged in the learning process.

Numerous studies exemplify the crucial role that political scientists contribute to the development of a politically engaged population. One reason examined by the summaries is that U.S. society is undergoing a vast change in demographics while at the same time an increasingly connected world results in the events of other nations directly influencing students in the United States. If our political discipline successfully incorporates current events and contemporary issues, we have a much greater ability to aid our students with a greater comprehension of a diverse world domestically as well as internationally (American Political Science Association, 2011).

Students' self-checking and a self-assessment of own activity are formed in the course of political education, it will become important quality of the person in the future. Bases of independence, responsibility, initiative in life lies in internal reflexive processes of the person. The reflection matters for personal development in that aspect, that it gives an idea of the purposes, content and means of own activity, it allows critically to treat activity, including public.

In the course of training at the universities students need to be able to carry out a reflection of own actions, and it assumes the whole complex of abilities.

- The ability to exercise control of own intellectual and practical actions.

- To control logic of expansion of own opinion (judgments).

- To define the sequence and hierarchy of stages of activity.

- The ability to carry out dialectic approach to the analysis of a situation, to become on a position of various "observers".

- The ability to explain political processes of the modern world and analyze them depending on the interests of own state.

Reflexive processes are an obligatory component of educational activity of the students therefore reflexive abilities need to be formed purposefully at them (Novikov, 2005).

The American Political Science Association (2011) in the fundamental research has proposed the modernization of political science in the following directions.

Through fundamental research, the American Political Science Association (2011) has proposed several ways to enhance the modernization of political science. To begin, a higher emphasis on open dialogue about critical world issues amongst people of diverse cultures and backgrounds should be sought to help enhance a move to internationalization in order to better align political science with other disciplines. The net effect of this process will be to give our students a greater awareness of the complexity and unique nature of foreign political systems and cultures and to ease cross-border communication. This in turn will serve to create a bridge between local and global views and move away from a solely "Westernized" global view. Additionally, our students should be given guidance on the application of classroom theories to real-life contemporary situations. This process could include removing students from familiar surroundings and providing alternate perspectives from all standpoints to include issues like racism, prejudice and nationalism. At a practical level, international internships would function to intertwine academic theory with real-world experience. Finally, the aforementioned concepts should be promoted while taking care not to overuse or misuse applicable terminology. Words such as "tolerance" or "multi-cultural,' for example, tend to be so over-circulated in contemporary media that they almost lose their meaning entirely and become nothing more than buzzwords.

Besides, acquisition of experience of political activity has to be provided with institutes of civil society, in particular the youth organizations, after all the transformation of information to political knowledge happens because of its ratio to personal experience of the young person. It is created the systems of public youth associations for today in Ukraine which number constantly grows. Despite it, most of them remain numerous little-known for youth and is not for it authoritative and prestigious. It while a problem of youth associations - stimulation independent the organized participation in politics. Because of activity political consciousness and the culture of the young man is formed.

Effective functioning of youth formations and associations is important where the authorities of norm, the rules of behavior are formed, duties and responsibility are established. The acquisitions of 
practical political experience, skills of democratic activity of youth has to be provided by consolidation of efforts of the youth organizations.

In this case it will be interesting the Report of the Task force on democracy, economic security, and social justice in a volatile world prepared by American Political Science Association (2012).

This report has put forth the idea that the practical application of different strategies to improve democracy and enhance economic security and social justice are closely interwoven in the political landscape. Democracy cannot exist without effective citizenship, of which economic and political citizenship are essential component. Preconditions for economic citizenship include a guarantee of economic rights that ensure public services, as well as a public means to finance these services while overall serving to moderate economic inequality. To attain political citizenship, it is not only imperative to provide guaranteed political and civil rights, but to also achieve a legitimate and accountable participation of citizens in the governing process where government responds directly to the will of the people. Hence, the common thread woven throughout the foundation of democracy is the protection and preservation of fundamental rights which is, of course, a central component to democracy in general.

In our case, the discussion of the underlying importance of "rights" as a foundation of democracy is no mere coincidence. Human rights-based approaches (HRBA), participatory governance (PG) and economic citizenship have been highlighted to underscore their interwoven nature and identify no potential areas of research. In world that is becoming increasingly volatile, the future of democracy is perhaps growing somewhat ambiguous. Serious issues ranging from inequality and poverty to economic mismanagement can all be considered threats to the very future of democracy as a practical and effective form of government. It is essential that the interconnections and innovations of democratic societies be openly shared and discussed across cultures and borders to ensure the health of the democratic process.

We have definitively identified human rights to be a crucial component to the universal foundation of democratic government, therefore it has become essential to gain a more thorough understanding of how these rights can be established and protected. This process can be achieved through a variety of methodologies with the goal of enhancing economic security as well as social justice. It has been our goal to highlight these innovative approaches as well as to examine how the different concepts are interrelated. Additionally, we seek to stimulate further research into the innovations we have discussed with the desired objective of better enabling our discipline to practically utilize these concepts to broaden our field of study (American Political Science Association, 2012).

The creation of conditions for personal development as citizen of Ukraine acts as the main goal of the Ukrainian education system (as civil and political). It assumes formation at children and youth of democratic outlook and political culture, an active civic and professional position. Besides, education of respect for language, culture, history of the people living in Ukraine, formation of culture of the interethnic relations is important. It will become a basis for consolidation of the Ukrainian people in the Ukrainian political nation as a set of citizens of the country, irrespective of their social-group distinctions have not only the equal rights and duties, but also the general political culture.

Ukrainian youth must have feelings of solidarity and patriotism instilled within them as well as knowledge of what is embodied in a normal political process to embark on the path of selfgovernment and the realization of a sovereign system. A primary characteristic of political socialization is the establishment of a national identity in young citizens and a desire to belong their country. In case valuable and standard system of society is weakened, then political socialization is not successful and then there is a reproduction of the destructive potential which is saved up in society.

Importance of a uniform system of political education proves the fact that political socialization happens in the Ukrainian society in different social and economic, sociocultural circumstances and different at the children belonging to different social groups and communities. The situation is 
complicated also by the fact that modern institutions of education and education in Ukraine are at the stage of constant reforming.

Investigating what values for Ukrainians are key it should be noted that the National Institute of strategic researches conducted sociological survey on this subject. Methodological tools of research methods were described in the analytical work of Ukrainian researchers Chupriy and Gai-Nizhnyk (2014). The main values are presented in Table 1.

Table 1. The system of values

\begin{tabular}{|l|c|}
\hline Value & $\mathbf{\%}$ \\
\hline Welfare & 46,5 \\
\hline Justice & 44,3 \\
\hline Stability & 40,9 \\
\hline Human rights & 37,4 \\
\hline Order & 36,1 \\
\hline Equality before the law & 30,2 \\
\hline Freedom & 18,1 \\
\hline Spirituality & 14,6 \\
\hline Patriotism & 13,1 \\
\hline Mutual aid & 10,1 \\
\hline Efficiency & 4,1 \\
\hline
\end{tabular}

Sources: Chupriy and Gai-Nizhnyk (2014)

The main typical lines of Ukrainians are presented in researches of values of the different people of Europe, made by the European sociological institutes (European Social Survey, n./d.). Researches show, that such lines as concern about own safety, inability to independently make decisions, aspiration to self-affirmation (the status, wealth, power) alerted the relation to changes, poorly expressed aspiration to enjoy life, are the main typical lines of Ukrainians (European Social Survey, n./d.).

Analysts note that the majority of these lines were created as a result of lack of confidence in tomorrow. Researchers note that the typical Ukrainian cardinally differs from the typical inhabitant of the majority of the European countries with long-term democracy, stable economy and the low index of corruption of governing bodies - for example, from the Scandinavian states of Denmark or Sweden and the countries of the northwest of the continent, such as Holland, Belgium, France and Germany (Chupriy \& Gai-Nizhnyk, 2014).

Staff of Institute of Sociology of National Academy of Sciences of Ukraine actively researches values. So, Ruchka (2010) investigating valuable priorities of the population of Ukraine, allocates five valuable syndromes. The first valuable syndrome covers the vital values - health (4.74 points on a $5^{-}$ mark scale), family (4.72), children (4.67), welfare (4.67). The second valuable syndrome covers social values: creation in the society of various opportunities for all, favorable moral and psychological climate in society, social equality (4.06). The third valuable syndrome covers traditionalist values: national and cultural revival, participation in religious life (3.47). The fourth valuable syndrome covers value self-realization: interesting work, public recognition, increase in educational level, expansion of a cultural outlook (3.70). The fifth valuable syndrome covers political and civil values: the state independence of the country, democratic development of the country, participation in activity political parties and public organizations (3.51). That is the vital and social values are the priority according to Institute of Sociology of National Academy of Sciences of Ukraine. The results of this research are shown in Table 2. 
Table 2. Values of Ukrainians

\begin{tabular}{|l|c|}
\hline Values & GPA \\
\hline Health & 4,74 \\
\hline Family & 4,72 \\
\hline Welfare & 4,67 \\
\hline Children & 4,67 \\
\hline Social equality & 4,06 \\
\hline National and cultural revival, religion & 3,47 \\
\hline Self-realization & 3,70 \\
\hline Political and civil values & 3,51 \\
\hline
\end{tabular}

Sources: Ruchka (2010)

Ukrainian researchers rather thoroughly investigated a problem of the national values. Scientific structured the system of national values and allocated the following levels of values - values of the individual, value of society, value of the state. The individualism, patriotism, the rights and freedoms, the right of a private property, universal values belong to the values of the state. Such values as natural resources, the constitutional system, national security and the state sovereignty, the system of international relations and directly territorial integrity belong to values of the state. Such social values as justice, welfare, interfaith and interethnic consent, liberal and democratic traditions, material and spiritual achievements belong to national values (Gorbulin \& Kachinsky, 2009; Ruchka, 2010).

According to above-mentioned researchers, further development and existence of the state and the nation has to be considered making a start from its valuable kernel which includes spiritual property, welfare, the system of international relations, social justice, patriotism and directly national security which consolidates society.

For this reason, the problems of political and civic education in Ukraine demand further detailed studying. In particular, the special attention is required by a question of inclusion of political knowledge in educational programs, developments of the manuals on political education, which corresponded the requirements of democratic society, promoted formation of knowledge and civil skills.

This process can be aided by recommendations provided by the American Political Science Association. Information garnered from the APSA's Teaching and Learning conferences can be employed to produce new educational techniques that incorporate more focus on current events and greater inclusiveness in curriculum. The political science discipline can be at the forefront of an effort to spearhead an investigation of issues associated with vast and complex demographical and political changes in the United States and numerous other countries. One of the core missions of political science is the analysis of the victors and losers in the political arena. As such, political science is ideally positioned to aid citizens in recognizing the direct consequences of their own choices as well as that of their government. A political science classroom is the ideal venue from which to communicate information that can truly enable citizens to empower themselves to make changes that will directly influence their futures (American Political Science Association, 2011).

\section{Discussion}

Due to the significance of the aforementioned dialogue, it becomes necessary to evaluate the controversy induced by the use of the terms "civic (citizenship) education" and "political education" in the context of use with European countries. It is noteworthy that citizenship education in developed democracies is a compulsory school subject that has been taught for several years (in France - all 12 years of schooling, in Spain - 9). The Concept of Citizenship Education Development in Ukraine (Protasova \& Poltorak, 2018) provides for an integrated (in the content of several disciplines) and cross-sectoral approach to the implementation of citizenship education at the higher education 
level. The question of what is the main category of civic education, what is its content regarding to the development of political culture of citizens, remains open.

Civic education, as noted by Napiontek (2013), was referred to as political education at the beginning of the 9os, since the field of knowledge it covered was politics, participation in elections, citizens' awareness of the activities of supreme authorities. However, the modern development of democracy significantly expands the scope of civic education because, in countries with a culture of participation, civic education aims to create an active citizen who would take part in policy-making on his or her own (Napiontek, 2013).

According to other scholars, the term "political education" was widely used in communist countries before 1989, and is therefore controversial today because it is associated with political propaganda. The Council of Europe was one of the first on the continent to feel the urgency of the problem and to launch the Education for Democratic Citizenship programm (Butt-Pośnik, ButtPośnik \& Widmaier, 2013). In Germany, for example, the scientific lexicon does not contain the term "civic education" at all, but instead uses the term "political education" (Germ. Politische Bildung) (Butt-Pośnik, Butt-Pośnik \& Widmaier, 2013, p. 206).

The importance of training educators in civic education was highlighted by British researchers White (2006) and Volpp (2007). Another British researchers Bergamini (2018) and Carter (2016) insisted on compulsory civic education. In his work, Carter (2016) writes about the lack of serious perception of civic education and disregard for political education. Turkey has witnessed a sharp rise in the amount of studies relating to citizenship and political education (Kuş \& Tarhan, 2016).

Returning to Ukraine, civic education here is a relatively new sphere of scientific and public interest. The current state of affairs generates uncertainty and lack of formation of the position regarding the place and role of civic education in the system of formal and non-formal education. Although, here is a rapid increase in the number of studies concerning the citizenship education (Bondar \& Ishakova, 2015; Semenets-Orlova, 2018; Semenets-Orlova \& Kyselova, 2018; Trapeznikova, 2016).

Ukrainian scholar Ivanov (2003), makes a clear distinction between civic and political education, including politology in scientific discussions. In his opinion, the mentioned terms cannot in any way be identified, but at the same time, the scholar does not exclude that they have much in common. If we consider political and civic education, the common feature for them will be the political and functional level, when the entire resource of both systems is mobilized to solve certain tasks of the society. But at the level of knowledge of the political world, civic and political education have very different objectives. As for political education and politology, Ivanov (2003) defines the first as "a system of transferring knowledge about political life by means of all social institutions that disseminate knowledge about it to a greater or lesser degree" (p. 43), and the second as "a system of professional education of specialists in the field of political process" (p. 43).

The need for advanced citizenship is growing with the strengthening of Ukrainian statehood. The processes of decentralization, self-improvement of politics, a new quality of democracy and a new social reality (the need to cooperate effectively in communities for the collective good) need a new model of patriotism for modern Ukraine. Living culture requires the creation of new values, although all of them should be discussed according to the criterion of respect for human dignity (Teaching and learning for a sustainable future, n./d.). Therefore, for example, the countries that are leaders in the academic performance of young people reconfigure educational systems into a valuebased approach, being aware of the growing demand for the value core of the individual for peaceful coexistence in a complex world. An important characteristic of the outlook of people who have devoted themselves entirely to social activity is social service, which is associated with a sense of duty towards others. Trust, belief in justice involves the voluntary commitment of members of society to exercise public functions.

New educational programs in the field of citizenship education in democratic countries are based on theory of famous researchers Almond and Verba (1989) highlighted the following signs of civil culture: a sense of pride in their nation, an expectation of a fair attitude to the society on the part of the authorities, a tolerant attitude to the opposition parties, active participation of the community 
in local self-government, confidence in one's ability to participate in politics, civil cooperation and trust, citizens' membership in autonomous associations. In this context, the scientists' view of the meaning of the term "civil culture" can be described as "enlightened patriotism".

A well-known philosopher Habermas (1996), in his work argues that the normative meaning of democratic citizenship can be determined without the formation of an individual in the context of a "national state". A theorist Starkey (2002) has a similar position, he claims that the concept of "citizenship" in its meaning always has a political and legal dimension. Although citizenship is in some way linked to a national concept, it is an autonomous and independent theory. In this context, Starkey (2002) observes that in the new concepts, citizenship exists also at supranational levels. Unlike Starkey (2002), the Irish researcher Craith (2004) argues that although the basis of modern citizenship is the focus on civil responsibility, it is the cultural forces (the value attitude of the individual to the state, the country and its citizens) that implicitly fasten components of modern citizenship. Our position correlates with the Irish researcher's point of view.

Today, the link between political and civic education and the term patriotism is widely discussed. The Stanford Philosophical Encyclopedia gives the standard definition of "patriotism" as follows: it is love for one's country (The Stanford Encyclopedia of Philosophy Archive, 2017). Other scholars point out that patriotism must be understood as a commitment and a sense of belonging to one's country (Françoise, 2013). Its meaning is usually related to its role in supporting national cohesion on behalf of the state to the extent that the state encourages members of society to respect their civil responsibilities. The consideration of this question varies greatly from one context to another, so theorists suggest talking about "patriotism" in plural, stating the diversity of its manifestations (Françoise, 2013).

Patriotism as the main category of political education can be defined as a system of views (cultural, consciousness attitudes) that reflect the inflexible attachment of a person to a particular country, characterized by an indisputable positive assessment of that country, persistent loyalty and intolerance to critics. In Western political philosophy, there is a debate about the type of patriotism that can provide an effective alternative to nationalism, as a meta idea for a stable statehood (The Stanford Encyclopedia of Philosophy Archive, 2017).

In this position, a meaningful assessment of morality as a universal regulator of the world of the future is important, which, in particular, the author of the theory "The Black Swan" Taleb (2014) substantiated. Methodologically valuable is the vision of the discrepancy between the notions of "nationalism" and "patriotism" (as main categories of political education) by the theorist Acton (1949): "patriotism, unlike nationalism, is the awareness, first of all, of our moral responsibilities to the socio-political community" (p. 163).

The results of sociological research (according to data for 2018) indicate a low level of awareness among Ukrainian youth of the political issues (Figures 1-4) related to the content of civic education (Protasova \& Poltorak, 2018).
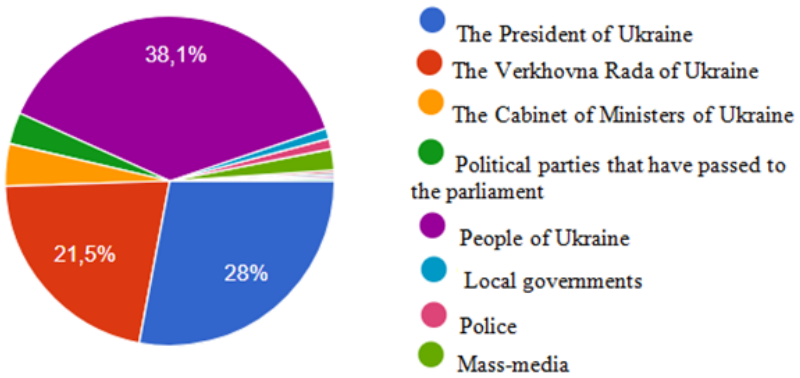

Figure 1. Distribution of answers of respondents to the question: "Who is the source of power in Ukraine?" (Ukrainian pupils in general, \%) 

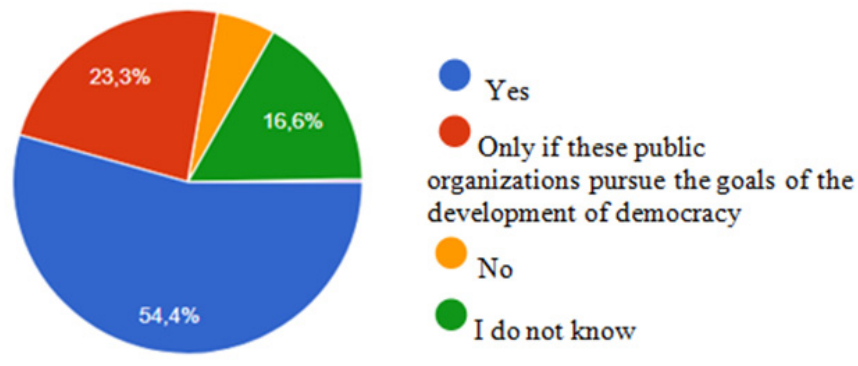

Figure 2. Distribution of respondents' answers to the question: "Is the activity of public organizations and associations of citizens important for the development of democracy in society?" (Ukrainian pupils in general, \%)
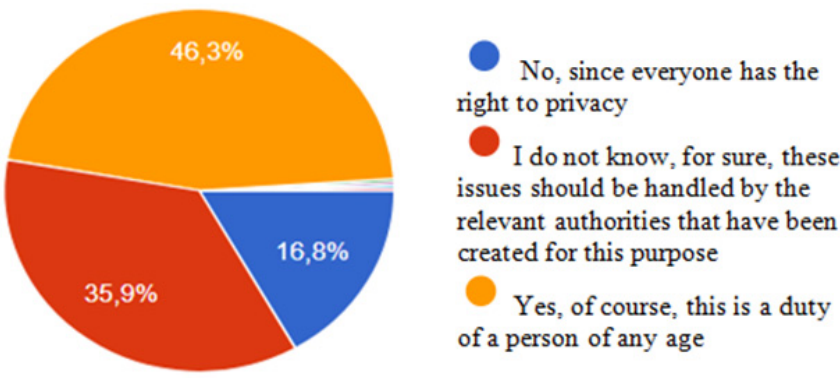

Figure 3. Distribution of respondents' answers to the question: Should a citizen give part of his time and efforts to develop democracy in Ukraine? (Ukrainian pupils in general, \%)
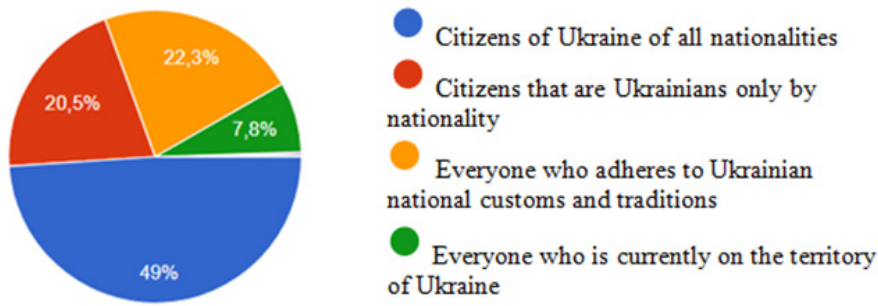

Figure 4. Distribution of respondents' answers to the question: "Ukrainian people is ..." (Ukrainian pupils in general, \%)

The results of the study showed that pupils have a vague idea of their civil identity. Thus, $49 \%$ believe that the Ukrainian people are citizens of Ukraine of all nationalities. At the same time, 20.5\% consider that citizens are only Ukrainians by nationality, and $22.3 \%$ - all those who adhere to Ukrainian national customs and traditions. Only 38.1\% of pupils know that the source of power in Ukraine is the people. At the same time, $28 \%$ erroneously believe that it is the President of Ukraine, while $21.5 \%$ is the Verkhovna Rada of Ukraine (Protasova \& Poltorak, 2018).

Following the above study, at the heart of modern citizenship is the focus on civil responsibility. However, the value attitude of the individual towards the state, the country and its citizens contributes to the consolidation of society and the strengthening of the components of modern citizenship. Today it is a positive phenomenon that the Ukrainian state has standardized the need for 
the development of citizenship competencies (documented in the law).

To succeed in a modern society, an individual is not enough to be a narrow specialist in a particular industry. Developed democracy implies that all members of society, despite their professional daily activities, must have the necessary knowledge in the field of democratic citizenship.

\section{Conclusions}

According to above-mentioned researchers, further development and existence of the state and the nation has to be considered making a start from its valuable kernel which includes spiritual property, welfare, the system of international relations, social justice, patriotism and directly national security which consolidates society. The further introduction of state programs of civil and political education in educational institutions is the leading direction of harmonization of process of political socialization of youth in the Ukrainian society. These programs have to include the formation of civil identity, feeling of solidarity and patriotism at children and youth. The educational component of political socialization has to be complemented with practical experience. Acquisition of skills of political activity at youth can be provided by consolidation of efforts of the youth organizations and political parties.

According to the authors of the article, civic education should be implemented by civil society institutions in the leading role of the state in the educational process. The state is the main institution of political education, provides a single educational space, creating a system of education and upbringing. The system of education and upbringing ensures the entry of new generations into a complicated world of politics. Its content is the organic inclusion in the complex system of political relations and institutions through the formation of models of political behavior, the presentation of political roles, preparation for political life. Unlike civil, political education is based on the application of advances in Political Science and has a phased nature. Therefore, among the main tasks of the educational process is the assimilation of political and legal knowledge.

The reorientation of society into new democratic values has already begun. Today, a number of concepts of civic education have been developed in Ukraine, as the Ministry of Education and Science of Ukraine and the Academy of Pedagogical Sciences of Ukraine take part in this process. Civic education should be implemented in the content of the entire education system, what is mentioned in the National Doctrine on the Development of Education in Ukraine.

In addition, civic education should be implemented by civil society institutions, in particular, youth organizations, because the transformation of information into political knowledge is due to its correlation with the personal experience of a young person. Nowadays a number of effective steps have been taken in Ukraine in this direction: there were created systems of public youth associations. In spite of this, most of them remain non-numerical, little-known to young people, and are not authoritative and prestigious for them. This is despite the fact that the task of youth associations is to stimulate young people's initiatives to actively engage in independent political participation. After all, it is through activity that the political consciousness and culture of a young person are formed.

The support of the youth initiative, the desire of young people to participate in society and the state in an organized way, should be a priority in the activity of state bodies to the independent realization of needs and interests. What is important is the effective functioning of youth organizations and associations where government rules, rules of behavior, obligations and responsibilities are established. By consolidating the efforts of youth organizations, it is necessary to ensure the acquisition of practical political experience, skills of political activity of youth.

The primary focus of Ukrainian civil and political education is the establishment of conditions that permit individuals to develop into Ukrainian citizens. The result of these conditions should include the formation of a democratic outlook and political culture in the youth, an active civil and professional position, the preservation and continuation of the cultural and historical tradition, the upbringing of respect for state symbols, institutes, as well as language, cultures, the history of peoples 
living in Ukraine, the formation of a culture of interethnic relations, an orientation towards the consolidation of the Ukrainian people in the racial political nation as a set of citizens of the country. These Ukrainian citizens should, regardless of their socio-group differences, possess not only equal rights and responsibilities, but a singular political culture based on a sense of solidarity and patriotism. Furthermore, they should engage in democratic governance based upon constitutionally defined procedures and processes to ultimately achieve a state of political sovereignty.

\section{References}

Acton, J. E. (1949). Nationality. In Essays on Freedom and Power (pp. 141-170). Boston: The Beacon Press.

Almond, G. \& Verba, S., (1989). The civic culture: Political Attitudes and Democracy in Five Nations. London: Sage Publications, Inc.

Almond, G., \& Verba, S. (1992). Civil culture and stability of democracy. Polys, 4, 123-134.

American Political Science Association. (2011). Political Science in the 21st Century. Report of the Task Force on Political Science in the 21st Century. Retrieved from https://www.apsanet.org/portals/54/Files/Task\%2oForce \%20Reports/TF_21st\%20Century_AllPgs_webres9o.pdf

American Political Science Association. (2012). Democratic Imperatives: innovations in rights, participation, and economic citizenship. Report of the Task force on democracy, economic security, and social justice in a volatile world. Retrieved from https://www.apsanet.org/portals/54/Files/Task\%2oForce\%2oReports /TF_DemocracyReport_FinalıD_15o.pdf

Bergamini, M. (2018). Compulsory political education is a must if we are to stem the flow of disengagement from politics. Democratic Audit. Retrieved from http://www.democraticaudit.com/?p=766o.

Bondar, L. \& Ishakova, N. (2015). Reflection as a main component of student learning activities. Proceedings of the National Aviation University. Pedagogy. Psychology, 1(6), 39-43.

Butt-Pośnik, J., Butt-Pośnik, M., \& Widmaier, B. (2013). Uczestnictwo obywatelskie i polityczne - czy mamy doczynienia $\mathrm{z}$ «efektem przenikania» (spill-over effect) [Civic and political participation - are we dealing with a "spill-over effect"?]. In A. Kordasiewicz \& P. Sadura (Eds.) Edukacja obywatelska w dziataniu [Civic education in action] (pp. 197-219). Warszawa: Wydawnictwo Naukowe Scholar.

Carter, W. (2016). The strange neglect of political education - and how to revive it. New Statesman. Retrieved from https://www.newstatesman.com/politics/education/2016/o8/strange-neglect-political-education-and-howrevive-it

Chupriy, L., \& Gai-Nizhnyk, P. (2018). Mational interests, national values and national goals as structural factors of national security policy. Gilea, 84(5), 465-471.

Craith, N. M. (2004). Culture and citizenship in Europe. Questions for anthropologist, 3, 289-300.

European Social Survey. (n./d.). Ukraine. Documents and data files. Retrieved from https://www.europeansocialsurvey.org/data/country.html?c=ukraine

Françoise, D. (2013). Les diversités du patriotisme contemporain. Critique international, 1(58), 9-17. doi:10.3917/crii.058.0009

Gorbulin, V. P., \& Kachinsky, A. B. (2009). Ambassadors of the National Security of Ukraine. Kyiv: Intertekhnologiya.

Habermas, J. (1996). Between Facts and Norms: Contributions to a Discourse Theory of Law and Democracy. Cambridge, MA: MIT Press.

Heitmeyer, W., \& Jacobi, J. (1991). Politische Sozialisation und Individualisierung. Perspektiven und Chancen politischer Bildung [Political socialization and individualization. Perspectives and opportunities of political education]. Weinheim: Juventa.

Hu, Z., \& Li, J. (2018). Innovative Methods for Ideological and Political Education of College Students. Educational Sciences: Theory \& Practice, 18(5). https://doi.org/10.12738/estp.2018.5.106.

Iskhakova, N. (2018a). The stages of political adaptation of the population in the process of

democratization. Gilea, 130(3), 366-370.

Iskhakova, N. (2018b). Trust as a factor of political mobilization of society in the conditions of establishment of democracy. Ukrainian Policymaker, 3, 11-16.

Ivanov, M. (2003). What is "civic" and what is "political" education? Political management, 2, 41-49.

Kuş, Z., \& Tarhan, O. (2016). Political Education in social studies classrooms: a perspective from Turkey. Journal of Theory and Practice in Education, 12(3), 464-483. 
Napiontek, O. (2013). Szkoła - przestrzeń obywatelskiego uczesnictwa [School - a space for civic participation]. In A. Kordasiewicz \& P. Sadura (Eds.) Edukacja obywatelska $w$ działaniu [Civic education in action] (pp. 104127). Warszawa: Wydawnictwo Naukowe Scholar.

Novikov, A. M. (2005). Methodology of educational activity. Moscow: Publ. «Egves».

Protasova, N., \& Poltorak, V. (Eds.). (2018). Analytical report on the results of the monitoring of the impact of the Swiss-Ukrainian project "Development of Civic Competences in Ukraine - DOCCU". Kyiv: Osnova.

Przeworski, A. (1991). Democracy and the Market: Political and Economic Reforms in Eastern Europe and Latin America. Cambridge; New York: Cambridge University Press.

Ruchka, A. (2010) Value mentality of the age groups of society. Sociological studies of culture. Kiev: Institute of Sociology

Semenets-Orlova, I. A. \& Kyselova, Ya. Ya. (2018). Multidimensional management contemporary: generation of social meanings for a new collective identities. Public management, 4(14), 264-273.

Semenets-Orlova, I. A. (2018). Tendencies in reforming the educational system of modern Ukraine: national and regional aspects. Public management, 2(12), 191-200.

Shcherbinin, A. I. (1996). Entry into the political world (theoretical and methodological bases of political didactics). Polys. 5, 136-146.

Shestopal, E. B. (1988). Personality and politician. Critical sketch of modern western concepts of political socialization. Moscow: Mysl.

Starkey, H. (2002). Democratic citizenship, languages, diversity and human rights. Guide for the development of Language Education Policies in Europe. From Linguistic Diversity to Plurilingual Education. Strasbourg: Council of Europe.

Szkudlarek, T. (2013). Comparative and International Education Education and the Political, http://dx.doi.org/10.1007/978-94-6209-383-6.

Taleb, N. (2014). Antifragile: Things that gain from disorder. New York: Random House Trade Paperbacks.

Teaching and learning for a sustainable future. (n./d.). Active citizenship in schools. Retrieved from http://www.unesco.org/education/tlsf/mods/theme_b/modo7.html?panel=3\#top

The Stanford Encyclopedia of Philosophy Archive. (2017). Patriotism. Retrieved from https://plato.stanford.edu/archives/sum2017/entries/patriotism/.

Trapeznikova, D. (2016). "Cold Shower" for human rights activists. Retrieved from https://day.kyiv.ua/uk/article/cuspilstvo/holodnyy-dush-dlya-pravozahysnykiv

Volpp, L. (2007). The Culture of Citizenship. Theoretical Inquiries in Law, 8(2), 571-602.

White, P. (1977). Political Education in a Democracy: The Implications for Teacher Education. Journal of Further and Higher Education, 1(3), 40-55.

Zhadan, I., Kiselyov, S., Kiselyova, O., \& Ryabov S. (2004). Political culture and problems of civic education in Ukraine: methodical manual. Kyiv: Tandem. 